\title{
EVALUATION OF EXISTING SLAUGHTER ACT AND WAY FORWARD TO ITS DEVELOPMENT IN BANGLADESH
}

\author{
M.R. Haque, M.A. Hashem", M.A. Akbar and M.M. Hossain \\ Department of Animal Science, Bangladesh Agricultural University \\ Mymensingh-2202, Bangladesh
}

\begin{abstract}
This study was undertaken for the evaluation of existing animal slaughter and meat quality control act 2011 and way forward to its development in Bangladesh. Published data, SWOT analyses, structured questionnaires survey, Focus Group Discussions (FGDs) and Key Informant Interviews (KIIs) were carried out for critical analyses and explore the different stakeholder's views. The study was carried out in seven divisions of Bangladesh namely Dhaka, Chittagong, Rajshahi, Khulna, Sylhet, Barisal and Rangpur. Total 285 representative samples (covering all stakeholders like farmers, butchers, meat processors, ULO/VS/PDO) were interviewed. Four FGDs and 50 Klls were administered with different stakeholders. Descriptive statistics like percentage, mean, ranks and Binary logistic regression and $Z$ test were used for data analyses. Findings show that the authority is not functioning properly due to lack of action plan and monitoring cell. Lack of certification authority, sanitary and meat inspector visit, restricted day, pre-slaughter and post-slaughter examination is visible. Act should be updated time to time to address the field based need. The study reveals that to implement the slaughter act Department of Livestock Services (DLS) as authority should have action plan and monitoring cell.
\end{abstract}

Keywords: Slaughter act, quality, safe meat, action plan, implementation

\section{INTRODUCTION}

According to the estimate of the Department of Livestock Services, the present population of cattle, goat, buffalo and poultry is about 23.44 million, 25.61 million, 1.45 million and 307.47 million, respectively in 2012-13 (DLS, 2014). There is a huge gap between the demand and supply of nutritious foods for the human population. An adult people require at least $250 \mathrm{ml}$ milk, $120 \mathrm{~g}$ meat daily, but supply

*Corresponding authors email: hashem_mdabul@yahoo.com

Received: 10.04.2017 
is about $44 \mathrm{ml}$ milk and $20.6 \mathrm{~g}$ meat per day (DLS, 2009) which indicates that we are in serious shortage of milk and meat. According to DLS report (2010), annual deficiency of milk, meat and egg is $82.28 \%, 80.22 \%$, and $62.20 \%$, respectively.

The livestock sub-sector in Bangladesh is currently governed by the following legislation: Bengal Cruelty to Animals Act, 1920, Prevention of Cruelty to Animals Ordinance, 1962, Bangladesh Veterinary Practitioners Ordinance, 1982, Animal Disease Act, 2005, Bangladesh Animal and Animal Product Quarantine Act, 2005, National Livestock Development Policy, 2007, National Poultry Development Policy, 2008, Avian Influenza Compensation Strategy and Guidelines, 2008, Bangladesh Zoo Act, 2009 (Draft), Animals Slaughter and Meat Control Act, 2011, Fish Feed and Animal Feed Act, 2010, National Livestock extension policy, 2012 (http://www.dls.gov.bd/livestockdevpolicy.php). These pieces of legislation will continue to be updated from time to time in accordance with the policy changes and production trends. In any given country, it is the role of a Government Ministry to develop appropriate policy guidelines for development of the sector the Ministry is involved in. However, development of such policies must involve all the key stakeholders for the guidelines to adequately address real problems and gaps that hinder the development of a sector.

All the attempts in livestock sector development are running to increase production in respect of milk, meat and egg. No activity has yet been taken giving special emphasis for producing safe and healthy food in relation to Hazards Analysis and Critical Control Point (HACCP), Good Management Practices (GMP) and Sanitary and Phytosanitary (SPS). In spite of having increased production of animal protein the consumers are not getting safe food as well as the animal industrialists can not export their products as per World Trade Organization (WTO) regulations. The dynamic potential of this emerging sub-sector thus requires critical policy attention. Although gains have been achieved in the sector to some extent, several gaps still exist that have not been addressed in the previous policies. There is need to give direction to the industry by putting in place a policy that will guide the development of the livestock sub-sector in Bangladesh. The policy needs to be reviewed from time to time, taking into account the dynamics of the domestic, regional and global socio-political and economic environment.

With above facts and circumstances to gain new explanatory insight a holistic survey analysis was carried out having different stakeholders on existing animal slaughter act, with the following objectives:

(i) Critical analysis of the existing slaughter act in Bangladesh.

(ii) To explore the implementation status of slaughter act with different stakeholders.

(iii) To identify the gaps between existing slaughter act and expectations from the perspective of stakeholders on the implementation. 
(iv) To recommend the output of the study to the concerned policy makers of the Government of Bangladesh.

\section{MATERIALS AND METHODS}

\section{Selection of the study area}

The study was carried out in seven divisions namely Dhaka, Chittagong, Rajshahi, Khulna, Sylhet, Barisal and Rangpur. These seven divisions were chosen as these locations are contributing significantly in livestock and poultry sector of Bangladesh.

\section{Selection of sample and sampling technique}

Table 1 shows the sampling technique of the study. Total 285 representative samples (covering all stakeholders) were interviewed from selected seven divisions consisting 116 farmers, 64 butchers, 66 Meat processors, 39 Government officials of livestock sector (Table 1). In addition, four FGDs (Focus Group Discussions) at BAU, DLS, BLRI, field level and 50 Key Informant Interviews (KII) were administered with different stakeholders.

Table 1. Population, Sample Size and Sampling Techniques

\begin{tabular}{|c|c|c|c|c|}
\hline Objectives & Data Source & Divisions & Population & Sample \\
\hline One & $\begin{array}{l}\text { Secondary sources: } \\
\text { desk review, BBS, } \\
\text { DLS, BER, Scientific } \\
\text { articles, Internet, } \\
\text { Compendium, SWOT } \\
\text { analyses }\end{array}$ & - & - & $\begin{array}{l}\text { Animal } \\
\text { slaughter act }\end{array}$ \\
\hline Two & $\begin{array}{l}\text { FGDs (Four), KIIs (50), } \\
\text { Questionnaire survey }\end{array}$ & $\begin{array}{l}\text { Seven } \\
\text { divisions, } \\
\text { BAU, DLS, } \\
\text { BLRI }\end{array}$ & $\begin{array}{l}\text { Livestock owners, meat } \\
\text { processors, butchers, } \\
\text { DLS personnel, } \\
\text { academicians, } \\
\text { researchers \& consumers }\end{array}$ & $\begin{array}{c}10-12 \text { persons } \\
\text { in each FGD, } \\
50 \text { KIIs }\end{array}$ \\
\hline Three & $\begin{array}{l}\text { Questionnaire survey, } \\
\text { KIIs, FGD }\end{array}$ & $\begin{array}{l}\text { Seven } \\
\text { divisions }\end{array}$ & $\begin{array}{l}\text { Livestock owners, meat } \\
\text { processors, butchers, } \\
\text { DLS personnel, } \\
\text { academicians, } \\
\text { researchers \& consumers }\end{array}$ & 285 \\
\hline Four & Previous sources & - & - & - \\
\hline
\end{tabular}

SWOT Analysis

A SWOT analysis was carried out to critically analyze the existing animal slaughter act. This tool was used for policy-review approach aiming at Strengths, 
Weaknesses, Opportunities and Threats (SWOT) analysis of the existing slaughter act in Bangladesh (Pearce et al., 2012).

\section{Preparation of survey instruments and pre-testing}

To collect the required data, four types of questionnaires were prepared in accordance with the objectives set for the study. Questionnaires then pre-tested in the field among some stakeholders before final data collection. After pre-testing, the final questionnaires were prepared after making necessary corrections, modifications and adjustment.

\section{Data collection and processing}

The research relies on both primary and secondary data. Secondary information were sought from various publications, DLS reports, previous survey reports, compendium and the strategic plan documents of the Ministry of Livestock and Fisheries. Primary data were collected by the trained enumerator including the researcher himself through face to face interview.

\section{Data analyses}

Descriptive statistics like percentage, mean and ranks were used for different variables to describe the present status of different stakeholders. Binary logistic regression was used to identify the variables influencing the slaughter act. Most of these analyses were conducted by using the statistical package named SPSS 20 .

\section{RESULTS AND DISCUSSION}

\section{Study on SWOT analyses of animal slaughter act, 2011}

Animal slaughter and meat quality control act, 2011 enacted with effect from 20 September 2011. The strength, weakness, opportunities and threats of the animal slaughter act are summarized in table 2 .

Table 2. Result of SWOT analysis of the animal slaughter act 2011

\begin{tabular}{|c|c|c|c|c|}
\hline No. & Strength & Weakness & Opportunities & Threats \\
\hline 1 & $\mid \begin{array}{l}\text { Restriction of slaughtering } \\
\text { outside slaughterhouse } \\
\text { defined in section } 3(1-2) \text {. }\end{array}$ & \begin{tabular}{|lr} 
Butchers & are \\
slaughtering & animal \\
outside & the \\
slaughterhouse. &
\end{tabular} & $\begin{array}{l}\text { To verify whether animal } \\
\text { is being slaughter outside } \\
\text { or not. }\end{array}$ & $\begin{array}{ll}\text { Non-cooperation } & \text { from } \\
\text { butchers and } & \text { meat } \\
\text { inspectors. } & \end{array}$ \\
\hline 2 & $\begin{array}{l}\text { Slaughtering restricted animal } \\
\text { is prohibited prescribed in } \\
\text { section } 4(1-2) \text {. }\end{array}$ & $\begin{array}{l}\text { Pregnant, lactating and } \\
\text { under aged animal may } \\
\text { be slaughtered. }\end{array}$ & $\begin{array}{l}\text { Govt may add provision } \\
\text { to ban the slaughtering of } \\
\text { restricted } \\
\text { Identified. }\end{array}$ & $\begin{array}{l}\text { Threats from animal } \\
\text { supplier, butchers etc. }\end{array}$ \\
\hline 3 & $\begin{array}{l}\text { Examination of health of pre- } \\
\text { slaughter and post-slaughter } \\
\text { of animal and carcass is well } \\
\text { defined in section } 5(1-2) \text {. }\end{array}$ & $\begin{array}{l}\text { Lack of pre-slaughter } \\
\text { and post-slaughter of } \\
\text { animal and carcass. }\end{array}$ & $\begin{array}{l}\text { Defect of provision can } \\
\text { be found out }\end{array}$ & $\begin{array}{ll}\text { Non-cooperation } & \text { from } \\
\text { corrupt vet. and } & \text { from } \\
\text { other stakeholders. } & \end{array}$ \\
\hline 4 & $\begin{array}{l}\text { Environment of } \\
\text { slaughterhouse in section } 6 .\end{array}$ & $\begin{array}{l}\text { Lack of } \\
\text { environment }\end{array}$ & $\begin{array}{l}\text { To find out the defect } \\
\text { slaughterhouse. }\end{array}$ & $\begin{array}{l}\text { Pressure may create } \\
\text { unlawfully from traders. }\end{array}$ \\
\hline
\end{tabular}




\begin{tabular}{|c|c|c|c|c|}
\hline No. & Strength & Weakness & Opportunities & Threats \\
\hline & & 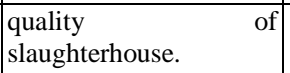 & & \\
\hline 5 & $\begin{array}{l}\text { Setting up of slaughterhouse, } \\
\text { meat selling and processing } \\
\text { plant is shown in section } 7 .\end{array}$ & $\begin{array}{l}\text { Does not follow the } \\
\text { provision under the act. } \\
\text { Lack of monitoring. }\end{array}$ & $\begin{array}{l}\text { To find out the provision } \\
\text { duly applied in setting up. }\end{array}$ & $\begin{array}{l}\text { Non-cooperation and } \\
\text { discourage to implement } \\
\text { the provision from DLS. }\end{array}$ \\
\hline 6. & $\begin{array}{l}\text { License for slaughterhouse, } \\
\text { meat selling and processing } \\
\text { plant is given in section } 8 \text { (1- } \\
\text { 2). }\end{array}$ & $\begin{array}{l}\text { Without license holders } \\
\text { it may be practiced. }\end{array}$ & $\begin{array}{l}\text { To check whether meat } \\
\text { stakeholders are licensed } \\
\text { holders or not. }\end{array}$ & $\begin{array}{l}\text { Humiliation and physical } \\
\text { assaults. }\end{array}$ \\
\hline 7. & $\begin{array}{l}\text { Process of licensing shown in } \\
\text { section in } 9 \text { (1). }\end{array}$ & $\begin{array}{l}\text { Might } \\
\text { fraudulence. }\end{array}$ & $\begin{array}{l}\text { To find out defect in the } \\
\text { process of application of } \\
\text { licensing. }\end{array}$ & $\begin{array}{l}\text { Non-cooperation from the } \\
\text { authority. }\end{array}$ \\
\hline 8. & $\begin{array}{l}\text { Period and renewal of license } \\
\text { stipulated in section } 10(1-3)\end{array}$ & $\begin{array}{l}\text { Period of license is very } \\
\text { minimal. }\end{array}$ & $\begin{array}{l}\text { To find out application } \\
\text { filed after termination of } \\
\text { license or } 60 \text { days before } \\
\text { termination. }\end{array}$ & $\begin{array}{l}\text { Non-cooperation } \\
\text { demand for bribe. }\end{array}$ \\
\hline 9. & $\begin{array}{l}\text { License held up and } \\
\text { cancellation defined in section } \\
11 .\end{array}$ & $\begin{array}{l}\text { Defective condition in } \\
\text { the processing of } \\
\text { licensing. }\end{array}$ & $\begin{array}{l}\text { To check of whether } \\
\text { license holders are } \\
\text { convicted for any offense } \\
\text { or violating any } \\
\text { condition. }\end{array}$ & $\begin{array}{l}\text { Offender may attack on } \\
\text { authority. }\end{array}$ \\
\hline 10. & $\begin{array}{l}\text { Power of entry and inspection } \\
\text { stated in section } 12(1-2)\end{array}$ & $\begin{array}{l}\text { Provision or act not } \\
\text { formulated in applying } \\
\text { judicial mind. }\end{array}$ & $\begin{array}{l}\text { To verify irrelevance in } \\
\text { the provision of act in } \\
\text { setting up slaughterhouse } \\
\text { related plant. }\end{array}$ & $\begin{array}{l}\text { Obstacle } \\
\text { confinement. }\end{array}$ \\
\hline 11. & $\begin{array}{l}\text { Health status of employees } \\
\text { working in slaughterhouse, } \\
\text { meat processing and selling } \\
\text { centre is shown in section } 13 \text {. }\end{array}$ & \begin{tabular}{|lr} 
Infected & employee \\
without & medical \\
treatment & may \\
& practice.
\end{tabular} & $\begin{array}{l}\text { Whether employee is } \\
\text { infected or free from } \\
\text { contagious disease. }\end{array}$ & $\begin{array}{l}\text { Contagious disease may } \\
\text { be spread. }\end{array}$ \\
\hline 12. & $\begin{array}{l}\text { Transport of animal, meat and } \\
\text { meat products stipulated in } \\
\text { section } 14(1-2) \text {. }\end{array}$ & $\begin{array}{l}\text { Lack of appropriate } \\
\text { provision. }\end{array}$ & $\begin{array}{l}\text { To find out whether } \\
\text { provision is being } \\
\text { followed in transporting. }\end{array}$ & $\begin{array}{l}\text { Threats may } \text { come from } \\
\text { stakeholders } \\
\text { confiscating, in } \\
\text { and destructing. }\end{array}$ \\
\hline 13. & 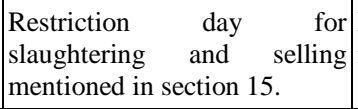 & $\begin{array}{l}\text { Not issuance of gazette } \\
\text { notification in time. }\end{array}$ & $\begin{array}{l}\text { To find out the restriction } \\
\text { day followed by butchers. }\end{array}$ & $\begin{array}{l}\text { Physical assaults or injury } \\
\text { may come from butchers. }\end{array}$ \\
\hline 14. & $\begin{array}{l}\text { Emergency slaughtering } \\
\text { stated in section } 16 .\end{array}$ & $\begin{array}{l}\text { Sick animal can be } \\
\text { slaughtered. }\end{array}$ & $\begin{array}{l}\text { To examine the health of } \\
\text { animals } \\
\text { slaughtering. }\end{array}$ & $\begin{array}{l}\text { Authority can be } \\
\text { corrupted. }\end{array}$ \\
\hline 15. & $\begin{array}{l}\text { Declaration to non-edible } \\
\text { meat stated in section } 17 .\end{array}$ & $\begin{array}{l}\text { May have non-edible } \\
\text { meat for eating whole } \\
\text { or part of carcass. }\end{array}$ & $\begin{array}{l}\text { To examine the whole or } \\
\text { part of carcass as edible } \\
\text { or non-edible. }\end{array}$ & $\begin{array}{l}\text { Without examination of } \\
\text { carcass non-edible meat } \\
\text { may enter to food chain. }\end{array}$ \\
\hline 16. & $\begin{array}{l}\text { Direction of destruction or } \\
\text { disposal of non-edible part of } \\
\text { whole or part of carcass and } \\
\text { offal explained in section } 18 \text {. }\end{array}$ & $\begin{array}{l}\text { Non-edible part of } \\
\text { whole or part of carcass } \\
\text { and offal may be edible. }\end{array}$ & $\begin{array}{l}\text { Whether non-edible part } \\
\text { of whole or part of } \\
\text { carcass and offal is } \\
\text { disposed of or destructed. }\end{array}$ & Diseases can be spread. \\
\hline 17. & $\begin{array}{l}\text { Direction to send the sample } \\
\text { at the laboratory stated in } \\
\text { section } 19 .\end{array}$ & $\begin{array}{l}\text { Laboratory test may not } \\
\text { be performed. }\end{array}$ & $\begin{array}{l}\text { To verify whether sample } \\
\text { may be tested or not in } \\
\text { proper way. }\end{array}$ & $\begin{array}{l}\text { Test might be done in } \\
\text { fake laboratory. }\end{array}$ \\
\hline
\end{tabular}




\begin{tabular}{|c|c|c|c|c|}
\hline No. & Strength & Weakness & Opportunities & Threats \\
\hline 18. & $\begin{array}{l}\text { Disposal of slaughter wastes } \\
\text { mentioned in section } 20 \text {. }\end{array}$ & $\begin{array}{l}\text { Irrelevant provision } \\
\text { might be formulated. }\end{array}$ & $\begin{array}{l}\text { Whether wastes are } \\
\text { disposed of according to } \\
\text { provision. }\end{array}$ & $\begin{array}{l}\text { Environment may be } \\
\text { polluted. }\end{array}$ \\
\hline 19. & $\begin{array}{l}\text { Standardization mentioned in } \\
\text { section } 24(1-2) \text {. }\end{array}$ & $\begin{array}{l}\text { Might have residual } \\
\text { affect of hormones, } \\
\text { antibiotics, } \\
\text { preservatives, } \\
\text { poisonous metals, } \\
\text { harmful organism in } \\
\text { meat. }\end{array}$ & $\begin{array}{l}\text { Whether safe meat is } \\
\text { being sold or not.. }\end{array}$ & $\begin{array}{l}\text { Hides, skin and meat } \\
\text { export may be difficult } \\
\text { and questionable.. }\end{array}$ \\
\hline 20. & $\begin{array}{l}\text { Seizure and disposal of meat } \\
\text { and meat products mention in } \\
\text { section } 22 \text {. }\end{array}$ & Might not practice. & $\begin{array}{l}\text { To explore about seizure } \\
\text { and disposal of meat and } \\
\text { meat products } \\
\text { accordingly. }\end{array}$ & $\begin{array}{l}\text { Authorities will get } \\
\text { scared execute the power. }\end{array}$ \\
\hline 21. & $\begin{array}{l}\text { Offence and trial stated in } \\
\text { section } 23(1-2) \text {. }\end{array}$ & $\begin{array}{l}\text { Lack of soundness of } \\
\text { mobile court practice. }\end{array}$ & $\begin{array}{l}\text { Mobile court act } 2009 \\
\text { whether being honestly } \\
\text { practiced or not. }\end{array}$ & $\begin{array}{l}\text { Executive magistrate can } \\
\text { work for Govt. }\end{array}$ \\
\hline 22. & $\begin{array}{l}\text { Punishment stated in section } \\
24(1-2) \text {. }\end{array}$ & Criminals may escape. & $\begin{array}{l}\text { Punishment should be } \\
\text { increased. }\end{array}$ & $\begin{array}{l}\text { Criminal may commit } \\
\text { offense repeatedly. }\end{array}$ \\
\hline 23. & Appeal stated in section 25 . & $\begin{array}{l}\text { Criminals may be } \\
\text { acquitted. }\end{array}$ & $\begin{array}{l}\text { To increase punishment } \\
\text { as well as fine. }\end{array}$ & $\begin{array}{l}\text { Slaughter act may not be } \\
\text { effective due to lack of } \\
\text { punishment. }\end{array}$ \\
\hline 24. & $\begin{array}{l}\text { Delivery of power explained } \\
\text { in section } 26 \text {. }\end{array}$ & $\begin{array}{l}\text { Animal production } \\
\text { professionals avoided in } \\
\text { this act. }\end{array}$ & $\begin{array}{l}\text { To bring back AH } \\
\text { graduate for the purpose } \\
\text { of meat quality and } \\
\text { control. }\end{array}$ & $\begin{array}{l}\text { Veterinary council and } \\
\text { vet are dead against to } \\
\text { recruit the } \mathrm{AH} \text { graduates. }\end{array}$ \\
\hline 25. & $\begin{array}{l}\text { Power of formulation of } \\
\text { provision mentioned in } 27 \text {. }\end{array}$ & $\begin{array}{l}\text { Dictator non elected } \\
\text { and non-participatory } \\
\text { Govt. may promulgate } \\
\text { gazette notification. }\end{array}$ & $\begin{array}{l}\text { Pro-people Govt can } \\
\text { promulgate provision. }\end{array}$ & $\begin{array}{l}\text { Repression, oppression, } \\
\text { death threat come from } \\
\text { constitutionally } \\
\text { illegitimate Govt. }\end{array}$ \\
\hline 26. & $\begin{array}{l}\text { Banning and sustaining the } \\
\text { act mentioned in section } 28 \\
(1-2) \text {. }\end{array}$ & $\begin{array}{l}\text { Lapse and gaps of the } \\
\text { existing act. }\end{array}$ & $\begin{array}{l}\text { Latest animal slaughter } \\
\text { act is well up-to-date or } \\
\text { not. }\end{array}$ & $\begin{array}{l}\text { Govt. might not be } \\
\text { interested. }\end{array}$ \\
\hline
\end{tabular}

\section{Farmers' knowledge about animal slaughter act}

Different variables in relation to farmer's knowledge about slaughter act are mentioned in table 3. There is a positive relationship between release of blood and bleeding time. Islam (2015) stated that time required for complete bleeding ranged from 9.13 to 16.35 minutes. Mobile court not conducted as per law. Adzitey et al. (2011) described that poor animal handling has adverse effects on the animal, carcass and meat quality. 
Table 3. Farmers knowledge about animal slaughter act, 2011

\begin{tabular}{|l|l|l|l|}
\hline Farmers knowledge & Yes (\%) & No (\%) & Ranks \\
\hline Knowledge about the irregular shape and flay-cuts & 53 & 47 & 1 \\
\hline Proper bleeding of animal done by the butcher & 47 & 53 & 2 \\
\hline Knowledge about the slaughter act & 42 & 58 & 3 \\
\hline $\begin{array}{l}\text { Butcher follow the age, sex, pregnancy and lactating considering } \\
\text { during slaughtering the animal }\end{array}$ & 40 & 60 & 4 \\
\hline Knowledge about the restricted day of slaughtering animal & 38 & 62 & 5 \\
\hline $\begin{array}{l}\text { Live animal and carcass examined to know healthy status at pre } \\
\text { slaughter and post slaughter time }\end{array}$ & 30 & 70 & 6 \\
\hline $\begin{array}{l}\text { Mobile court conduct for prohibiting the crime related to slaughter } \\
\text { act or not }\end{array}$ & 25 & 75 & 7 \\
\hline The butcher follow hang and pull system of flaying or not & 25 & 75 & 8 \\
\hline $\begin{array}{l}\text { Know without slaughterhouse no animal can be slaughtered except } \\
\text { for holly greatest festival and family feast }\end{array}$ & 23 & 77 & 9 \\
\hline Whether the existing slaughterhouse is environment friendly or not & 23 & 77 & 10 \\
\hline Sanitary inspector visit the slaughterhouse or not & 14 & 85 & 11 \\
\hline
\end{tabular}

\section{Knowledge and perception of butcher about animal slaughter act, 2011}

Table 4 reveals that more than $80 \%$ butchers sell their by-products like blood, bone, kidney, liver, stomach; have proper bleeding knowledge; slaughter should be done in slaughter house except festival. These all sorts of positive answer is a good which aligned to good management practices for Halal and safe meat production. During beef cattle fattening there is a report (Islam et al., 2012) wherein stated farmers having 2-5 heads of cattle are highly fattened using growth promoters like Oradexon (Glucocorticoid steroid), Decason (Glucocorticoid steroid), Dexavet (Synthetic Steroid), Tredexanol (Synthetic Steroid), Pednivet (Steroids). Sixty nine per cent butchers are license holders. It is mandatory to have license in slaughter act. Slaughterhouse and meat processing centre are not set up scientifically as per rules and provisions of the act. Most meat is handled in unhygienic sanitary conditions in both rural and urban areas in Bangladesh. Enforcement of legislation relating to slaughtering or meat inspection is weak (Murshed, 2014). Mobile court should be consisted of livestock expertise along with executive magistrate who is well versed in slaughter act. Food animals such as cattle, buffalo, sheep, and goats are brought to these slaughterhouses from long distances usually by driving or on the hoof. Since there is no lairage, animals generally do not receive ante mortem care (Rahman, 2001). 
Table 4. Knowledge and perception of butcher about slaughter act

\begin{tabular}{|c|c|c|c|}
\hline Particulars & Yes $(\%)$ & No $(\%)$ & Rank \\
\hline Selling of by-products & 91 & 9 & 1 \\
\hline Requirement of proper bleeding knowledge & 88 & 12 & 2 \\
\hline Slaughter should be done in slaughter house except festival & 86 & 14 & 3 \\
\hline The license must be renewed after one year is known to & 84 & 16 & 4 \\
\hline $\begin{array}{l}\text { Know } 4-5 \text { minutes is needed to have halal meat for proper } \\
\text { bleeding }\end{array}$ & 80 & 20 & 5 \\
\hline Heard about the restricted day of slaughtering animal or not & 75 & 25 & 6 \\
\hline Visit by meat inspector to give seal on carcass or not & 70 & 30 & 7 \\
\hline $\begin{array}{l}\text { Taken licenses to set up slaughterhouse, meat processing and sale } \\
\text { center from licensing authority or not }\end{array}$ & 69 & 31 & 8 \\
\hline $\begin{array}{l}\text { Slaughterhouse, meat processing center and plant set up as per } \\
\text { prescribed size and available facilities or not }\end{array}$ & 67 & 31 & 9 \\
\hline Visit slaughter house by sanitary inspector & 64 & 36 & 10 \\
\hline Any irregular shape and flay-cuts or not & 58 & 42 & 11 \\
\hline Introduce hang and pull system of flaying or not & 58 & 42 & 12 \\
\hline Cut on hides and skin during flaying or not & 55 & 45 & 13 \\
\hline $\begin{array}{l}\text { Care environmental safety (air, water) during slaughtering the } \\
\text { animal or not }\end{array}$ & 50 & 50 & 14 \\
\hline $\begin{array}{l}\text { The live animal and carcass has been examined to know healthy } \\
\text { status at pre slaughter and post slaughter time }\end{array}$ & 47 & 53 & 15 \\
\hline Follow binding age for animal for slaughter or not & 47 & 53 & 16 \\
\hline $\begin{array}{l}\text { Follow flaying and preservation of hides and skin as per } \\
\text { provision or not }\end{array}$ & 39 & 61 & 17 \\
\hline $\begin{array}{l}\text { Mobile court conducted for prohibiting the crime related to } \\
\text { slaughter act or not }\end{array}$ & 37 & 63 & 18 \\
\hline Animal has been kept at stockyard before slaughtering or not & 34 & 66 & 19 \\
\hline $\begin{array}{l}\text { Follow the provision of animal slaughter and waste disposal as } \\
\text { per Act or not }\end{array}$ & 23 & 77 & 20 \\
\hline $\begin{array}{l}\text { Has the meat contained the tolerable level of antibiotic, } \\
\text { preservative, hormone, poisons substance, heavy metal and } \\
\text { micro-organism }\end{array}$ & 19 & 81 & 21 \\
\hline Whether your slaughterhouse is environment friendly or not & 17 & 83 & 22 \\
\hline $\begin{array}{l}\text { The carcass, meat, consumable meat offal, used water and ice } \\
\text { collected for sample testing is examined by the veterinary public } \\
\text { health and microbiology laboratory or not }\end{array}$ & 11 & 89 & 23 \\
\hline
\end{tabular}




\section{Knowledge and perception of meat processor about slaughter act}

Table 5 shows that $74 \%$ meat processors used clean water in processing plant. Islam (2015) cited that $71.43 \%$ butchers clean their slaughter house/meat selling centre which is in agreement with the present findings. It reveals that $30 \%$ selling center are not certified by the authority which is the violation of the slaughter act. In many developing countries, regulations concerning meat inspection and/or control are inadequate or non-existent allowing consumers to be exposed to pathogens including zoonotic parasites (Adzitey and Huda, 2012). Perez et al. (2002) observed that a lairage period of two to three hours is necessary to recover from transport stress, because of reduced meat quality with shorter lairage times.

Table 5. Knowledge and perception of meat processor about slaughter act

\begin{tabular}{|l|l|l|l|}
\hline Particulars & Yes $(\%)$ & No (\%) & Rank \\
\hline Clean water is used in your processing plant or not & 74 & 26 & 1 \\
\hline $\begin{array}{l}\text { Whether the selling center is certified by the designated authority } \\
\text { or not }\end{array}$ & 70 & 30 & 2 \\
\hline $\begin{array}{l}\text { Whether the persons involved in meat processing are free from } \\
\text { infectious and contagious diseases or not }\end{array}$ & 62 & 38 & 3 \\
\hline $\begin{array}{l}\text { Certified by registered physician in getting cured from aforesaid } \\
\text { diseases or not }\end{array}$ & 39 & 61 & 4 \\
\hline $\begin{array}{l}\text { The DG or authorized officer inspects your meat processing } \\
\text { center/plant or not }\end{array}$ & 36 & 64 & 5 \\
\hline $\begin{array}{l}\text { Follow the provision of transport and marketing of meat and meat } \\
\text { products as per Act or not }\end{array}$ & 35 & 65 & 6 \\
\hline $\begin{array}{l}\text { Whether your slaughterhouse is environment friendly or not } \\
\text { Manager or owner or responsible person keep the medical } \\
\text { certificate of employees of processing plant/center, slaughterhouse } \\
\text { or not }\end{array}$ & 27 & 73 & 8 \\
\hline $\begin{array}{l}\text { Show the health certificate while veterinary surgeon inspect or not } \\
\text { act-2005 or not }\end{array}$ & 23 & 77 & 92 \\
\hline $\begin{array}{l}\text { There are modern facilities in your processing plant/center or not } \\
\text { Importing meat based onimal and animal products quarantine }\end{array}$ & 18 & 90 & 11 \\
\hline
\end{tabular}

\section{Knowledge and perception of ULO/DLO about slaughter act}

Table 6 shows that $82 \%$ Govt. officials does not follow the animal slaughter act. Farmers are in loss in livestock business due to lack of proper marketing and value of the product. 
Table 6. Knowledge and perception of ULO/DLO about slaughter act

\begin{tabular}{|c|c|c|c|}
\hline Particulars & Yes $(\%)$ & No $(\%)$ & Rank \\
\hline Follow the animal slaughter act or not & 18 & 82 & 1 \\
\hline $\begin{array}{l}\text { Working for entrepreneurship development or exporting } \\
\text { livestock products or not }\end{array}$ & 46 & 54 & 2 \\
\hline In case of animal importing quarantine facilities is created or not & 56 & 44 & 3 \\
\hline $\begin{array}{l}\text { Advise farmer for maintaining cool chain method in selling } \\
\text { dressed poultry }\end{array}$ & 56 & 44 & 4 \\
\hline $\begin{array}{l}\text { Get encourage and assist to set up disease diagnostic lab at } \\
\text { private level }\end{array}$ & 69 & 31 & 5 \\
\hline Maintain withdrawal period of drugs in prescription or not & 74 & 26 & 6 \\
\hline $\begin{array}{l}\text { Live bird marketing, bio-security in city corporation and } \\
\text { Pouroshava are mentioned in policy is known to it or not }\end{array}$ & 77 & 23 & 7 \\
\hline $\begin{array}{l}\text { Residual effect of medicine must not have in the poultry product } \\
\text { are maintaining or not }\end{array}$ & 77 & 13 & 8 \\
\hline $\begin{array}{l}\text { Long term planning in preventing and controlling diseases such } \\
\text { as bird flu and other infectious disease }\end{array}$ & 77 & 23 & 10 \\
\hline $\begin{array}{l}\text { Following international standard in case of using probiotic and } \\
\text { antibiotic }\end{array}$ & 77 & 23 & 11 \\
\hline Registered veterinary surgeon or not & 80 & 20 & 12 \\
\hline Bio-security protocol reached to the farmer or not & 82 & 18 & 13 \\
\hline $\begin{array}{l}\text { Taking initiative on epidemiology, disease reporting and } \\
\text { recording system }\end{array}$ & 85 & 15 & 14 \\
\hline Taking any initiative on disease control extension program & 85 & 15 & 15 \\
\hline Giving advice to the farmer not to sell live birds in case of & 85 & 15 & 16 \\
\hline $\begin{array}{l}\text { Getting encourage the farmer to sell dressed broiler and poultry } \\
\text { meat }\end{array}$ & 87 & 13 & 17 \\
\hline $\begin{array}{l}\text { While setting up farm, registration, control of food value, disease } \\
\text { control and others follow the act/provision/ordinance or not }\end{array}$ & 90 & 10 & 18 \\
\hline Followed the veterinary practitioner act or not & 92 & 8 & 19 \\
\hline $\begin{array}{l}\text { Non-registered veterinary surgeon not allowed to practice is } \\
\text { known or not }\end{array}$ & 92 & 8 & 20 \\
\hline The veterinary practitioner act is known or not & 95 & 5 & 21 \\
\hline $\begin{array}{l}\text { Any involvement in poultry disease surveillance at Govt. and } \\
\text { private level farm or not }\end{array}$ & 95 & 5 & 22 \\
\hline The animal slaughter act is known or not & 97 & 3 & 23 \\
\hline
\end{tabular}

\section{Binary logistic regression for butchers about slaughter act}

From binary logistic regression it reveals that none of the endogenous variables have significant effect on the knowledge of farmers about slaughter act. From proportion test ( $\mathrm{Z}$ test) it reveals that less than $50 \%$ of farmers have knowledge about the slaughter act and less than $40 \%$ of processors are known about the slaughter act. 


\section{Qualitative results on Focus Group Discussion (FGD) and KIIs}

We had four FGDs and KIIs with DLS personnel, University teachers and BLRI scientist. From the study it revealed that authority should have appropriate implementation strategy. Scientific slaughter house, chilling facility of fresh meat, important role of academician and researcher, health status of workers of slaughter house and processing plant, consumer's exploitation by butchers should be maintained. Policy should be implemented on step by step basis targeting a period. There should have sophisticated and accredited laboratories to carry out chemical analysis of feeds (de Jonge \& Jackson, 2013).

During illegal cross border traffic there is a possibility of transmission of transboundary diseases, loss of foreign currencies and threatens of livestock breeding policies and border killings (The Daily Star, August 10, 2015). If this illegal entry is blocked there will be an opportunity to increase own livestock resources through small scale and large scale livestock farming resulting in poverty reduction in the country (Ali and Hossain, 2014).

\section{CONCLUSION}

The study reveals that to implement the slaughter act authority should have action plan and monitoring cell in order to implement the slaughter act; establishment of modern scientific slaughterhouse; slaughtering license process should be transparent; cattle smuggling from neighboring countries should be controlled; act should be updated time to time to address the field based need.

\section{ACKNOWLEDGEMENTS}

The authors wish to acknowledge and thanks to BLRI, Savar, Dhaka for financial support.

\section{REFERENCES}

Adzitey, F. 2011. Effect of pre-slaughter animal handling on carcass and meat quality. International Food Research Journal, 18: 485-491

Adzitey, F. and Huda, N. 2012. Effects of post-slaughter carcass handling on meat quality. Pakistan Veterinary Journal, 32 (2): 161-164

Ali, Z. and Hossain, I. 2014. Barriers to the development of livestock sector in Bangladesh. Bangladesh Institute of Development Studies, Policy brief, 408: 1-8

De Jonge, L. and Jackson, F. 2013. The feed analysis laboratory: Establishment and quality control. Setting up a feed analysis laboratory, and implementing a quality assurance system compliant with ISO/IEC 17025: 2005

DLS. 2009. Department of Livestock Services, Government of the Peoples' Republic of Bangladesh 
DLS. 2010. Department of Livestock Services, Government of the Peoples' Republic of Bangladesh

DLS. 2014. Department of Livestock Services, Government of the Peoples' Republic of Bangladesh

Islam, M.H., Hashem, M.A., Hossain, M.M., Islam, M.S., Rana, M.S. and Habibullah, M. 2012. Present Status on the Use of Anabolic Steroids and Feed Additives in Small Scale Cattle Fattening in Bangladesh. Progressive Agriculture, 23: 1-13

Islam, M.S. 2015. Evaluation and grading of indigenous cattle of Bangladesh for beef production. A Dissertation for PhD. Department of Animal Science, Bangladesh Agricultural University, Mymensingh, Bangladesh

Murshed, H.M. 2014. Study on handling, processing and microbial quality of meat at Dhaka, Chittagong and Sylhet divisions in Bangladesh. MS Thesis, Department of Animal Science, Bangladesh Agricultural University, Mymensingh, Bangladesh

Pearce, J.A., Robinson, R.B., Mital, A. 2012. Strategic Management: Formulation, Implementation and Control, 12 ed. McGraw Hill: New Delhi, India

Perez, M.P., Palacio, J., Santolaria, M.P., Acena, M.C., Chacon, G., Gascon, M., Calvo, J.H., Zaragoza, P., Beltran, J.A. and Gracia-Belenguer, S. 2002. Effect of transport time on welfare and meat quality in pigs. Meat Science, 61: 425-433

Rahman, S.M.E. 2001. Cattle fattening through urea molasses straw and its effect on intake, growth and carcass characteristics. MS Thesis, Department of Animal Science, Bangladesh Agricultural University, Mymensingh.

The Daily Star. 2014. Use of tannery waste in poultry feed and antibiotic. The Daily Star 15 July 2014. pp 1

http://www.dls.gov.bd/livestockdevpolicy.php 